\title{
Anomalous colour in Neotropical mammals: a review with new records for Didelphis sp. (Didelphidae, Didelphimorphia) and Arctocephalus australis (Otariidae, Carnivora)
}

\author{
Abreu, MSL. ${ }^{a}$, Machado, R. ${ }^{a, b}$, Barbieri, F. ${ }^{a}$, Freitas, NS. ${ }^{a}$ and Oliveira, LR..$^{a, b *}$ \\ aLaboratório de Ecologia de Mamíferos, Universidade do Vale do Rio dos Sinos - UNISINOS, Av. Unisinos, 950, \\ Centro 2, bloco D, sala 2D221, CEP 93022-000, São Leopoldo, RS, Brazil

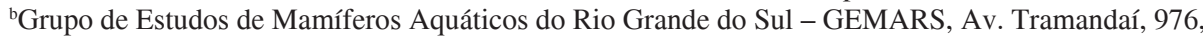 \\ CEP 95625-000, Imbé, RS, Brazil \\ *e-mail: lari.minuano@gmail.com
}

Received November 25, 2011 - Accepted April 2, 2012 - Distributed February 28, 2013

(With 1 figure)

\begin{abstract}
Anomalous colourations occur in many tropical vertebrates. However, they are considered rare in wild populations, with very few records for the majority of animal taxa. We report two new cases of anomalous colouration in mammals. Additionally, we compiled all published cases about anomalous pigmentation registered in Neotropical mammals, throughout a comprehensive review of peer reviewed articles between 1950 and 2010. Every record was classified as albinism, leucism, piebaldism or eventually as undetermined pigmentation. As results, we report the new record of a leucistic specimen of opossum (Didelphis sp.) in southern Brazil, as well as a specimen of South American fur seal (Arctocephalus australis) with piebaldism in Uruguay. We also found 31 scientific articles resulting in 23 records of albinism, 12 of leucism, 71 of piebaldism and 92 records classified as undetermined pigmentation. Anomalous colouration is apparently rare in small terrestrial mammals, but it is much more common in cetaceans and michrochiropterans. Out of these 198 records, 149 occurred in cetaceans and 30 in bats. The results related to cetaceans suggest that males and females with anomolous pigmentation are reproductively successful and as a consequence their frequencies are becoming higher in natural populations. In bats, this result can be related to the fact these animals orient themselves primarily through echolocation, and their refuges provide protection against light and predation. It is possible that anomalous colouration occurs more frequently in other Neotropical mammal orders, which were not formally reported. Therefore, we encourage researchers to publish these events in order to better understand this phenomenon that has a significant influence on animal survival.
\end{abstract}

Keywords: albinism, hypopigmentation, leucism, Neotropical mammals, piebaldism.

\section{Coloração anômala em mamíferos Neotropicais: uma revisão com novos registros para Didelphis sp. (Didelphidae, Didelphimorphia) e Arctocephalus australis (Otariidae, Carnivora)}

\begin{abstract}
Resumo
Colorações anômalas ocorrem em muitos vertebrados tropicais. Entretanto, estas são consideradas raras em populações selvagens, havendo poucos registros para a maioria dos táxons. Reportam-se, neste estudo, dois novos casos de coloração anômala em mamíferos. Além disso, por meio de uma extensa revisão bibliográfica, foram compilados os casos publicados sobre coloração anômala em mamíferos neotropicais entre 1950 e 2010. Cada registro foi classificado como albinismo, leucismo, piebaldismo ou, eventualmente, como coloração indeterminada. Como resultados, reportouse o registro de um espécime leucístico de gambá (Didelphis sp.) no sul do Brasil e de um espécime de lobo-marinho sul-americano (Arctocephalus australis) com piebaldismo no norte do Uruguai. Também foram analisados 31 artigos científicos, resultando em 23 registros de albinismo, 12 de leucismo, 71 de piebaldismo e 92 registros classificados como de pigmentação indeterminada. A coloração anômala aparentemente é rara em pequenos mamíferos terrestres, mas é muito mais comum em cetáceos e microquirópteros. Dos 198 registros encontrados, 149 ocorreram em cetáceos e 30 em morcegos. No caso dos cetáceos, este resultado sugere que machos e fêmeas com este padrão anômalo de pigmentação são reprodutivamente exitosos e, consequentemente, sua frequência está aumentando nas populações naturais. Com relação aos morcegos, este fenômeno pode estar relacionado ao fato de estes animais orientarem-se primariamente por meio de ecolocalização e seus refúgios oferecerem proteção contra luz e predação. É possível que a coloração anômala ocorra mais frequentemente em outras ordens de mamíferos neotropicais, as quais não foram formalmente reportadas. Desta forma, mostra-se importante encorajar os pesquisadores a publicar estes eventos em vida selvagem para um melhor entendimento deste fenômeno, que tem influência significativa na sobrevivência destes organismos.
\end{abstract}

Palavras-chave: albinismo, hipopigmentação, leucismo, mamíferos neotropicais, piebaldismo. 


\section{Introduction}

The two factors that determine colour patterns in mammals are the presence and distribution of pigmentation in the skin, hair and eyes (Fertl and Rosel, 2002; Hofreiter and Schöneberg, 2010). However, anomalous colour can occur occasionally due to an excess or deficit in the production of melanin in some regions of or throughout the entire body (Acevedo and Aguayo, 2008). According to Summers (2009), the terms "partial" and "total" for the two different levels of albinism (hypopigmentation) have become obsolete. Current zoological studies (Fertl and Rosel, 2002; Miller, 2005; Acevedo and Aguayo, 2008) have classified anomalous colouration as piebaldism, leucism (or partial albinism), albinism and melanism. There is still some divergence between authors, mainly because some studies do not take into account the differences between piebaldism and leucism (e.g. Geiger and Pacheco, 2006; Oliveira, 2009a).

Piebaldism is lack of pigmentation in some parts of the body, but presenting normal colouration in the eyes (Fertl and Rosel, 2002). Miller (2005) used the term partial albinism to refer to this phenomenon. Leucism are characterised by total or partial absence of pigmentation in the whole body (the individual has a body that is white, whitish or yellowish white colour), but the eyes and/or body extremities still have dark or blue pigmentation (Fertl and Rosel, 2002; Miller, 2005; Acevedo and Aguayo, 2008). Albinism records are those in which the individual presents a total absence of pigmentation in the whole body (white, whitish or yellowish white colour) and has eyes with no traces of pigmentation, but instead red or pink colouration (Fertl and Rosel, 2002; Miller, 2005; Acevedo and Aguayo, 2008).

Leucism, piebaldism, and albinism have been recorded in many species of Neotropical vertebrates, including snakes (e.g. Sazima and Di-Bernardo, 1991; Silva et al., 2010), anurans (e.g. Sanabria et al., 2010), birds (e.g. Veiga and Oliveira, 1995b; Franz and Fleck, 2009; Mancini et al., 2010), fish (e.g. Sazima and Pombal, 1986; Brito and Caramaschi, 2005) and mammals (e.g. Acevedo and Aguayo, 2008; Oliveira, 2009a, b). However, these events are considered rare in wild populations (Walter, 1914) because albino animals are more susceptible to predation (Sazima and Di-Bernardo, 1991; Parsons and BonderupNielsen, 1995) and there are a number of pathologies that can arise in association with the albinism, such as visual (Pérez-Carpinell et al., 1992; Grant et al., 2001; Garipis and Hoffmann, 2003) and immunological defects (Manglani et al., 2004; Summers, 2009; Carretero et al., 2009). In the case of aquatic animals, Hain and Leatherwood (1982) and Fertl and Rosel (2002) also suggest that albino animals may exhibit lower heat absorption in colder waters. Other authors suggest that the survival of albino animals does not differ from that of non-albino individuals of cryptic or nocturnal species (Sazima and Pombal, 1986; Sazima and Di-Bernardo, 1991) and in those that have restricted predators (Rodrigues et al., 1999). Therefore, in order to better understand the consequences of the anomalous coloration on the survival of wildlife mammals, it is essential to know the kind and frequency of these phenomena and the most susceptible orders.

In this paper, we review the cases of albinism, leucism and piebaldism recorded in Neotropical mammals. We also report new cases of anomalous colouration in Didelphis sp. Linnaeus, 1758 and Arctocephalus australis (Zimmermann, 1783).

\section{Material and Methods}

The new records of anomalous coloration reported here occurred in two opportunistic occasions. The photograph of the opossum was taken by Lieutenant Erneide Rissardo da Silva, from the Second Environmental Policy Squad (Segundo Pelotão de Policiamento Ambiental) of Torres, Rio Grande do Sul, Southern Brazil (for more details see the Results section).

The photograph of the South American fur seal was taken by one of the authors in Cabo Polonio, Rocha Province, Uruguay (for more details see the Results section). The authors of both pictures used a portable camera with $480 \mathrm{dpi}$ of resolution. It is important to mention that without the photographs mentioned above, the present records would not be available. Thus, we believe that this record is a very helpful tool for documentation of natural history.

We conducted a review of the records of anomalous colouration in Neotropical mammals published in peerreviewed journals between 1950 and 2010 through scientific portals (e.g. NCBI, Web of Science, Sciello, Sciello Brazil, Periódicos CAPES) using as key words the terms "albinism", "albinismo", "leucism", "leucismo", "anomalous color", "piebaldism", "piebaldismo" and "white color". We did not include any personal communications in the results. The papers found were analysed by species and mammal order, the country where the record occurred and type of hypopigmentation. For marine mammals, we only included cases documented on the Neotropical coastal waters. The Neotropical region is defined as Central Mexico to the southernmost tip of South America (Udvardy, 1975).

Piebaldism records are related to a lack of pigmentation in only some parts of the body and normal eye colouration. Leucism are a total or partial absence of pigmentation in the whole body, but the eyes and/or body extremities still have dark or blue pigmentation. Albinism are a total absence of pigmentation in the whole body and red or pink eyes. This classification was based on Fertl and Rosel (2002), Miller (2005) and Acevedo and Aguayo (2008). When the authors of the analysed studies classified an individual as having only total or partial albinism, a more refined classification was used (piebaldism, leucism or albinism), based on the record description and available photos. When the information presented was insufficient to properly classify the anomalous colour type, these records were classified as "undetermined". 


\section{Results}

In this paper, we report two new cases of anomalous colouration in Didelphis sp. and Arctocephalus australis. We also found 31 scientific articles with records of albinism, leucism and piebaldism in Neotropical mammals.

\subsection{Case 1: Record of opossum, Didelphis sp., with leucism}

On 27 August 2010, a specimen of Didelphis sp. was found in a commercial establishment in Arroio do Sal city, Rio Grande do Sul state, Southern Brazil $\left(29^{\circ} 33^{\prime} \mathrm{S}\right.$ and $\left.49^{\circ} 53^{\prime} \mathrm{W}\right)$. The animal was collected by the Second Environmental Policy Squad (Segundo Pelotão de Policiamento Ambiental) of Torres and released in the Environmental Reserve Tupancy Park (29 29' S and $49^{\circ} 50^{\prime} \mathrm{W}$ ), in Arroio do Sal. The animal presented a white colour throughout the entire body and dark eyes, representing a case of leucism (Figure 1a).

Since it was rescued and released by the Second Environmental Policy Squad, the specimen could not be identified for the species level. Two species of the genus Didelphis occur in Rio Grande do Sul: D. albiventris Lund, 1840 and D. aurita (Wied-Neuwied, 1826) (Wilson and Reeder, 2005; Vaccaro and Canevari, 2007; Rossi et al., 2010). Both species are listed as of least concern on the Red List of the International Union for Conservation of Nature (IUCN), but they are not listed under the Convention on International Trade in Endangered Species of Wild Fauna and Flora (CITES).

\subsection{Case 2: Record of South American fur seal, Arctocephalus australis, with piebaldism}

On 23 October 2010, a specimen of Arctocephalus australis was observed and photographed by one of the authors (NSF) in Cabo Polonio (34 $24^{\circ}$ S and $53^{\circ} 47^{\prime} \mathrm{W}$ ), Uruguay. The specimen, a sub-adult male, presented white spots in the ventral region, next to the neck and right pectoral fin (Figure 1b). These characteristics indicated that this is a record of piebaldism.

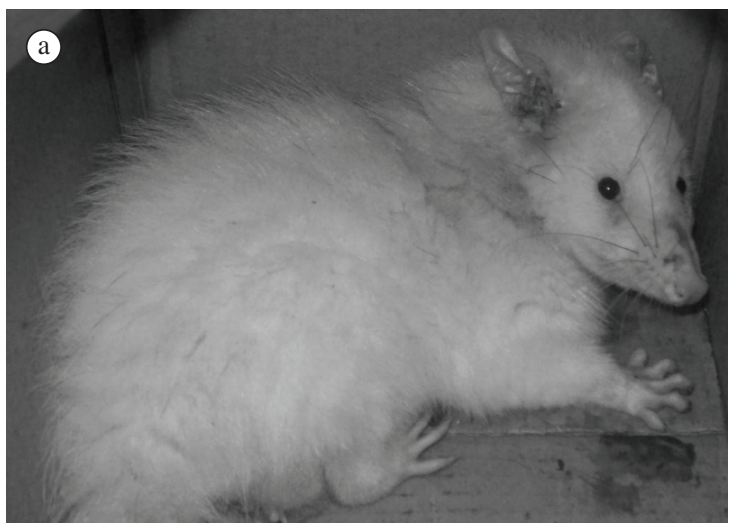

A. australis is a highly dimorphic pinniped, with males being larger than females. Until 1991, the main threat to the conservation of this species was poaching for skin and genitalia (Reeves et al., 1992). Currently, this species is protected and is listed in Appendix II of the CITES. In IUCN, the species is listed as of least concern on the Red List.

\subsection{Compilation of the records of anomalous coloration in Neotropical mammals}

Our review of the studies of anomalous coloration in Neotropical mammals resulted in 31 scientific articles and 198 individuals reported. Considering the records of the present study, we have 23 records of albinism, 12 records of leucism, 71 records of piebaldism, and 92 records classified as undetermined (Table 1). The Order Cetartiodactyla presented the largest number of records ( $\mathrm{n}=152$, including 149 cetaceans), followed by Chiroptera $(n=30)$, Carnivora $(n=9)$, Rodentia $(n=4)$, Pilosa $(n=2)$ and Didelphimorphia ( $\mathrm{n}=1$, present paper). Argentina was the country, which had most of the records $(n=150)$ followed by Brazil $(n=37)$, which presented cases in all orders that the phenomena was reported.

We were unable to verify whether the cases registered for Guiana dolphin, Sotalia guianensis (van Bénéden, 1864) (Nascimento et al., 2008), and Pantropical spotted dolphin, Stenella attenuata graffmani (Lönnberg, 1934) (Fertl et al., 2004), were of albinism or leucism because the authors were unable to check the colour of the individuals' eyes. For sperm whale, Physeter macrocephalus Linnaeus, 1758, Fertl et al. (1999) did not include much information about this record, restraining an appropriate classification. In relation to the records of the Southern Right whale Eubalaena australis (Desmoulins, 1822) presented by Schaeff et al. (1999), we considered the pattern of colorations "white-blaze" and "partial-grey-morph with white-blaze" as piebaldims and "grey-morph" and "partial-grey-morph" as undetermined, based on classification presented by these authors. Moreover, Schaeff et al. (1999) did not present the absolute number of individuals for each kind

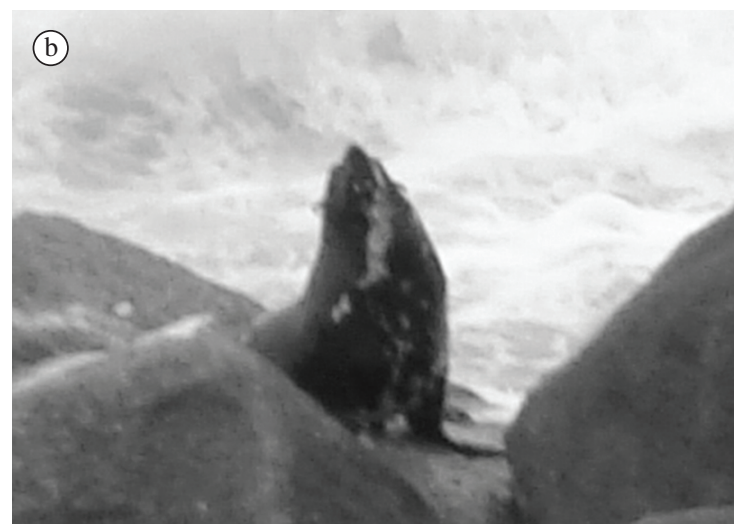

Figure 1. New records of anomalous colour in Neotropical mammals. (a) Leucistic opossum (Didelphis sp.) found on the coast of Rio Grande do Sul state, Southern Brazil (Photo: E.R. Silva). (b) South American fur seal (Arctocephalus australis) with piebaldism registered in Cabo Polonio, Uruguay (Photo: NS Freitas). 


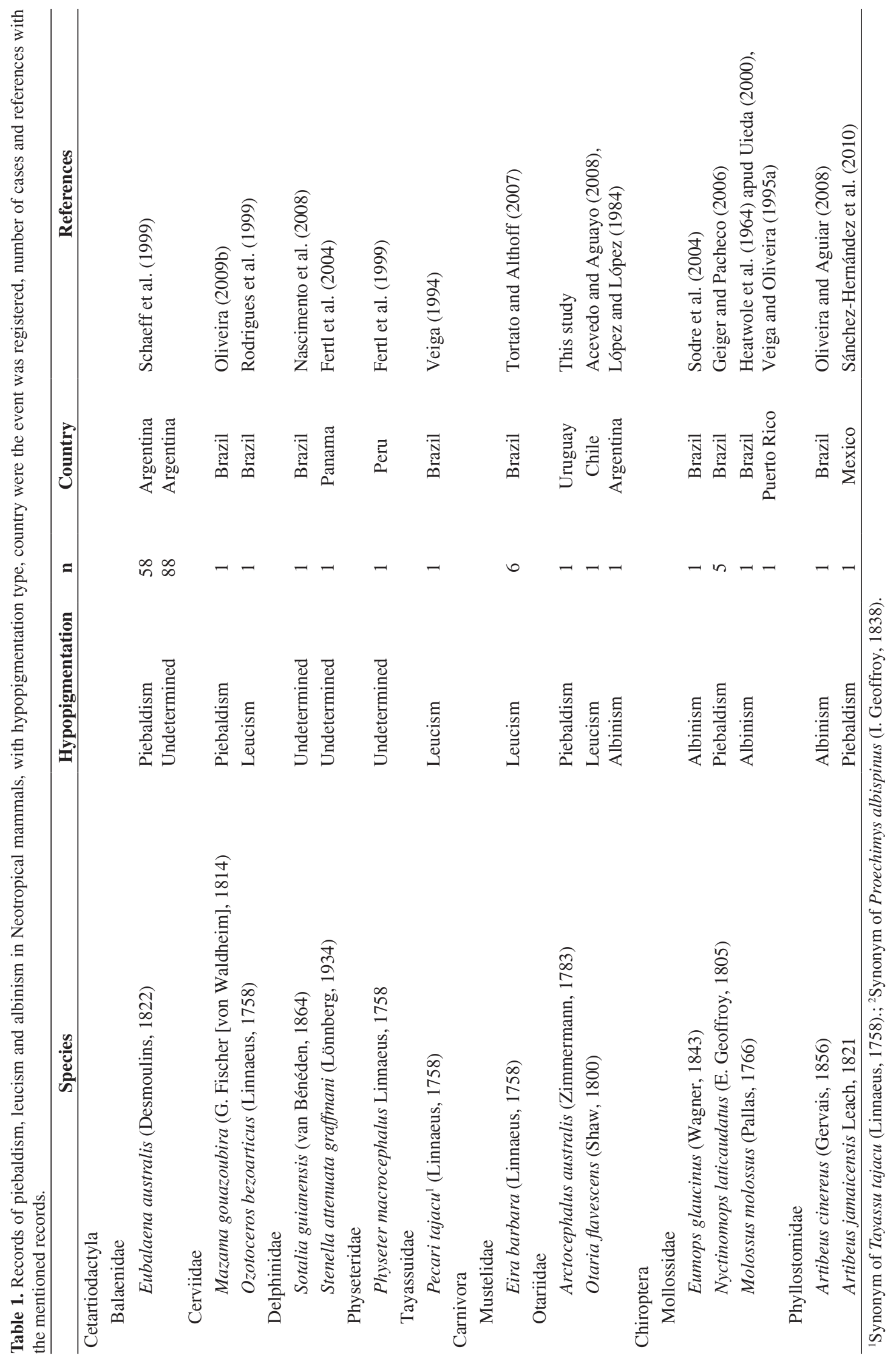




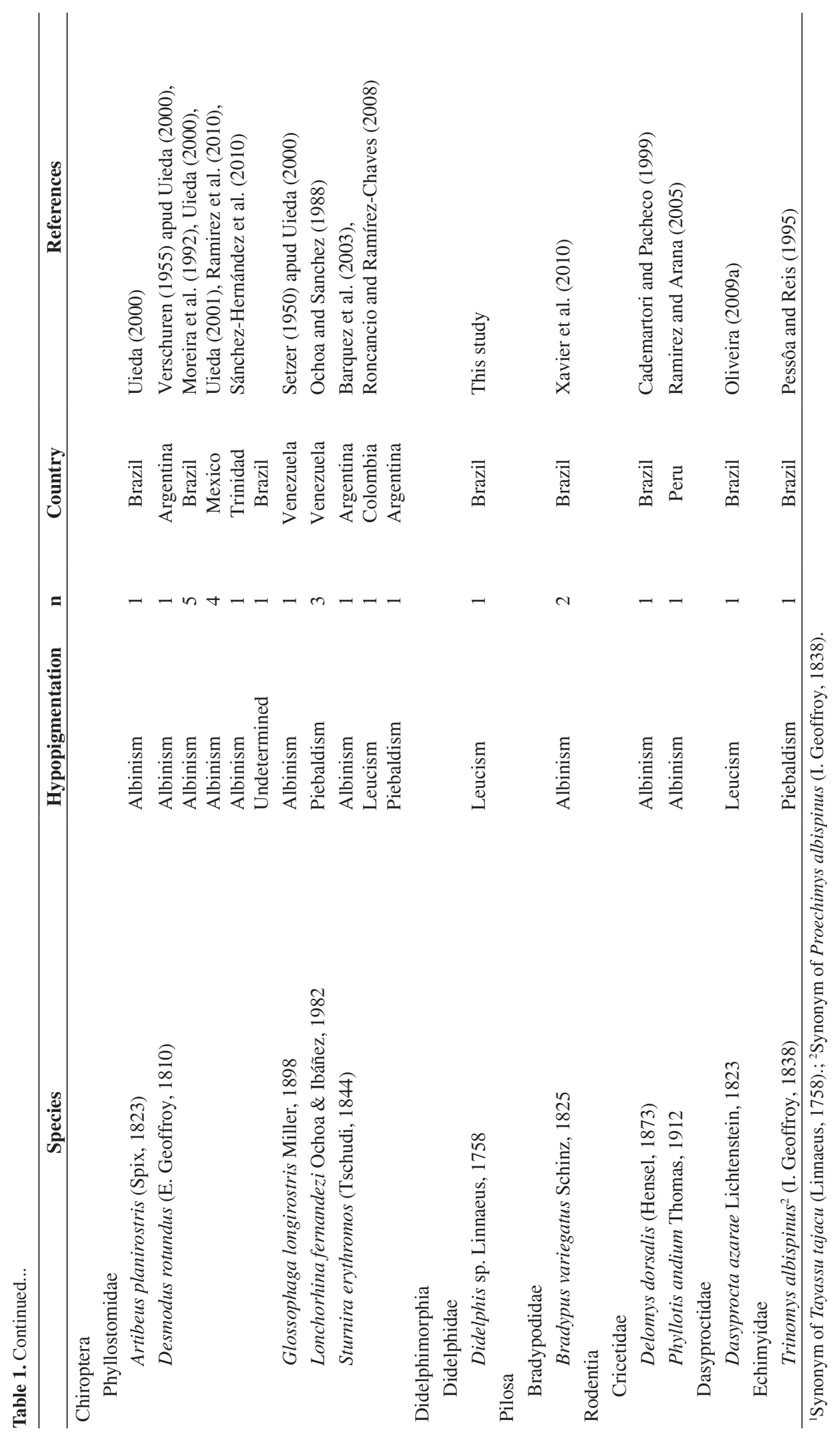


of anomalous coloration for the Southern Right whale. However, we were able to determine these values based on the frequency and total number of specimens presented in Table 2 of this paper (see Schaeff et al., 1999)

\section{Discussion}

In the present study, we found 198 cases of anomalous colouration in Neotropical mammals, and reported two new cases. The Order Cetartiodactyla had the highest number of records, including 59 cases of piebaldism, two cases of leucism and 91 records that we classified as undetermined. Moreover, 149 cetacean specimens were reported in scientific papers, including 146 Southern Right whales (Eubalaena australis) from the Argentine coast (Schaeff et al., 1999). According to Payne et al. (1983) five dorsal skin patterns have been documented among Southern Right whales: black, white-blaze, grey-balke, grey-and-whyte-blaze and partially albinistic. Partially albino right whales are white as calves but darken and become grey or brownish-grey as they age. Schaeff et al. (1999) suggested that two genes influence the dorsal skin color. The grey-morph and partial-grey-morph phenotypes (previously known as partial albino and grey-blaze, respectively) appear to be controlled by an X-linked gene, whereas the white blaze appears controlled by an autosomal gene (recessive phenotype). A number of forms of partial albinism have been identified in other mammals, including three which may be X-linked (Fraser et al., 1953; Tietz, 1963; Zipkowski et al., 1962).

In marine mammals, anomalously white individuals have been reported for 25 cetacean species and eight species of pinnipeds (otariids and phocids), with no known record for otters and sirenians (Acevedo et al., 2009). In the present study, we found articles reporting anomalous colouration in eight species of marine mammals, four otariids and four cetaceans (Table 1). However, Southern Right whales are the only species where such individuals are relatively common (Schaeff et al., 1999). According to Fertl and Rosel (2002), the costs of this anomalous colouration for marine mammals may include reduced heat absorption in colder waters, increased conspicuousness to predators, increased skin and eye sensitivity to sunlight, and impaired visual communication (Hain and Leatherwood, 1982). Despite the costs, some individuals do reach adult age and breeding status. The data presented by Schaeff et al. (1999) indicated that the occurrence of grey-morph females of southern right whale and the production of partial-greymorph calves by black cows (female whales with calves) suggested that grey-morph males are fertile. Moreover, comparison of observed and expected frequencies of partial-grey-morph calves suggests that grey-morph males were as successful as black males in achieving fetilizations with black cows. However, additional data are required to furher investigate the impact of dorsal color patterns on male fitness (Schaeff et al., 1999).

We also found many other records of aquatic mammals with anomalous colouration in other parts of the world outside of the Neotropical region (e.g. Hain and Leatherwood, 1982; Fertl et al., 1999; Bruyn et al., 2007; Acevedo and Aguayo, 2008; Acevedo et al., 2009). The record of piebaldism in South American fur seal, A. australis, reported in this study is the first report of atypical colouration for the species, but anomalous colour has been recorded in other otariid species. On an earlier review of this anomaly in otariids, Acevedo and Aguayo (2008) reported cases in five otariid species: Antarctic fur seal, Arctocephalus gazella (Peter, 1875), Northern fur seal, Callorhinus ursinus Linnaeus, 1758, Steller sea lion, Eumetopias jubatus (Schreber, 1776), Californian sea lion, Zalophus californianus (Lesson, 1828), and South American sea lion, Otaria flavescens (Shaw, 1800). According to Acevedo et al. (2009), atypical colouration is rare in marine mammals, but this anomaly seems to be frequent in Antarctic fur seals from South Georgia and the South Shetlands Islands. This may be due to a decrease in this species' population caused by hunting during the XIX and XX centuries. The proposed theory is that these populations suffered a founder effect after the reduction, and it is possible that one of the founder individuals had atypical colouration, which raised the levels of this anomaly in the population (Bonner, 1968; Cárdenas and Yañez, 1983; Hofmeyr et al., 2005).

The Chiroptera was the second most abundant order in terms of records of anomalous colouration, with 18 cases of albinism, ten cases of piebaldism, one case of leucism and one record that we classified as undetermined. Ramirez et al. (2010) mention a case of albinism for the dwarf little fruit bat, Rhinophylla pumilio Peters, 1865, in French Guiana. However, the authors did not make a reference of these records, which make the analysis of this case impossible. Uieda (2000) also mentioned records of albinism in the Parnell's mustached bat, Pteronotus parnellii Gray, 1843, large fruit-eating bat, Artibeus lituratus (Olfers, 1818), and big-eared bat, Macrotus waterhousii Gray, 1843, all registered in Mexico. However, we had no access to the papers that originally related the case, and we did not know if they occurred in a Neotropical region. These cases were not included in the results due to the lack of significant information (Table 1).

Geiger and Pacheco (2006) mentioned that $21.2 \%$ of the bats studied by the authors in southern Brazil (Rio Grande do Sul state, $29^{\circ} 36^{\prime} \mathrm{S}$; 52 $2^{\circ} 40^{\prime} \mathrm{W}$ ) showed some evidence of anomalous colouration. According to Uieda (2000), the survival of albino bats is not affected by this condition because bats' refuge provides light and predation protection. Moreover, these bats orient themselves primarily through echolocation (Feldhamer et al., 2007; Reis et al., 2007); hence, they are less affected by the visual problems associated with albinism. These factors may explain the higher incidence of anomalous colouration registered in flying mammals as compared to non-flying mammals.

In the present paper we report the first record of a Brazilian marsupial with leucism. Other cases of Neotropical small terrestrial mammals with anomalous colouration were registered on only three occasions and included one record of albinism in striped Atlantic forest rat, 
Delomys dorsalis (Hensel, 1873) (Cademartori and Pacheco, 1999), one case of piebaldism in white-spined Atlantic spiny-rat, Trinomys albispinus (I. Geoffroy, 1838) (Pessôa and Reis, 1995), and one case of albinism in Andean leaf-eared mouse, Phyllotis andium Thomas, 1912 (Ramirez and Arana, 2005). These reports are also uncommon in other parts of the world. We found one case of piebaldism in the common shrew, Sorex araneus Linnaeus, 1758 (Gelling, 2003), and one case of albinism in the hoary-bellied squirrel, Callosciurus pygerythrus (I. Geoffroy Saint Hilaire, 1833) (Kalita, 2009). Because they represent the base of the trophic web for most of the large and medium vertebrates, small terrestrial mammals suffer a high risk of predation (e.g. Juarez and Marinho-Filho, 2002; Magrini and Facure, 2008; Sousa and Bager, 2008; Abreu et al., 2010). Additionally, anomalous colouration tends to strongly reduce the survival of these organisms, since these deficiencies make them visible to predators (Sazima and Di-Bernardo, 1991; Parsons and BonderupNielsen, 1995). The visual problems associated with albinism (Pérez-Carpinell et al., 1992; Grant et al., 2001; Garipis and Hoffmann, 2003) can also result in a decrease of survival since these animals may be less capable of searching for resources and detecting predators.

In relation to terrestrial carnivores, Tortato and Althoff (2007) reported six records of tayras, Eira barbara (Linnaeus, 1758), with whitish yellow pelage in Santa Catarina state, Southern Brazil. These authors do not consider these records as albinism. However, following the classification adopted in the present study, we considered these cases as being records of leucism, since the animals presented some anomaly in the production of pigmentation. Presley (2000) suggested that albinism and the deficit in the production of pigmentation are more common in tayras than in other mustelids and mentioned the existence of a yellow morphtype in Guianas for tayras. We did not find records of anomalous colouration in other mustelids or in other terrestrial carnivorous mammals.

The Order Primates has at least 281 species in the world (Wilson and Reeder, 2005). Nevertheless, we did not find records of albino Neotropical primates in our review. The only record found was a personal communication mentioned by Veiga (1994) for the brown capuchin monkey, Cebus apella (Linnaeus, 1758). We found two records of hypopigmentation in primates from Africa: two records in the black crested mangabey, Lophocebus aterrimus (Oudemans, 1890) (Eppley et al., 2010) and one in the western gorilla, Gorilla gorilla (Savage, 1847) (Sabater Pi, 1967), showing that this anomaly is present in this order.

According to Wilson and Reeder (2005) the Order Pilosa has ten known species, all found in Central and Southern America. We found records of anomalous colouration only in the brown-throated sloth, Bradypus variegatus Schinz, 1825 (Xavier et al., 2010). The Order Cingulata, which is included in the superorder Xenarthra with Pilosa, is also predominantly Neotropical. All of the species are found in Central and Southern America, with the nine-banded armadillo, Dasypus novemcinctus Linnaeus, 1758, which is the only species that can be found in the southern part of North America (Wilson and Reeder, 2005). However, we found no record of anomalous colouration in the species of these orders in any part of their distribution.

Some of the analysed studies still indicate the possibility of the existence of other terrestrial Cetartiodactyla with albino traces. Veiga (1994) related cases of atypical colouration in the red brocket deer, Mazama americana (Erxleben, 1777), but these records are from personal communication, which make it impossible to confirm the type of anomaly. This author also mentioned a possible record of another individual of collared peccary, Pecari (=Tayassu) tajacu (Linnaeus, 1758), near São José dos Pinhais city (Paraná state) (2532' S; 49 $11^{\prime}$ W), Southern Brazil. In Midwestern Brazil (Goiás state), Rodrigues et al. (1999) mention a record of a pup of Pampas deer, Ozotoceros bezoarticus (Linnaeus, 1758), with albino characteristics (although they do not provide sufficient information to define the record as having albinism, leucism or piebaldism).

The high frequency of cases of atypical colouration of mammals in Argentina is probably due to the systematic and long term monitoring of the local population of the Southern Right whale (more than 20 years - Schaeff et al., 1999). However, in Brazil the number of records could be a direct result of the synergic effect among the large territorial area, the great mammal diversity and probably to the number of mammal specialists working in Brazil in comparison to other Neotropical countries (Reis et al., 2010). Nevertheless, this could just be an artefact of analyses that use only published papers, which ignores all the information presented in scientific congresses, popular science magazine articles, as well as personal communications. We know of the existence of some cases of anomalous colouration in Neotropical mammals that are not related in scientific papers, and are therefore not part of scientific community knowledge.

Anomalous colouration also occurs in mammals from other biographic regions of the world (e.g. Sabater Pi, 1967; Gelling, 2003; Kalita, 2009; Eppley et al., 2010). It is possible that cases of anomalous colour in some Neotropical mammalian orders are more frequent than related in this review. It is important to mention that there are probably many mammal specimens from different orders with anomalous colouration in museums and scientific collections inside and outside of Brazil, but collected in Neotropical region. Unfortunately, many of these records were not officially reported, probably due to the lack of knowledge by the collectors and/or collection managers about the importance of this phenomenon. Therefore, we highlight the relevance of photographs as valuable tools for documentation about natural history as a whole. In conclusion, researchers must be encouraged to report the records of albinism, leucism and piebaldism in wildlife in order to better understand this phenomenon and its insights into the ecological and physiological implications of this condition, which has a significant influence on animal survival (Fertl et al., 2004). 
Acknowledgements - The authors would like to thank Lieutenant Erneide Rissardo da Silva from the Second Environmental Squad (Segundo Pelotão de Policiamento Ambiental) from Torres, for the photos and information about the record of the leucistic Didelphis sp. We would like to thank Fernando Lopes and Lúcia Darsie Fraga for their discussion on this subject and suggestions of related papers, and the two anonymous referees for comments and suggestions on an earlier version of this manuscript. We would also like to thank Dr. Robert Leo Brownell Junior, who kindly reviewed the English and provided valuable comments and suggestions to improve this manuscript. Support for this research was provided by Coordenação de Aperfeiçoamento Pessoal de Nível Superior (CAPES): PROSUP Master's grant to MSLA and to RM. To UNISINOS which provided the scientific initiation grant to NSF (UNIBIC - Projeto PAE PP0000003119) and local facilities.

\section{References}

ABREU, MSL., WIELICZKO, AR., MESQUITA, A. and VIEIRA, EM., 2010. Consumo de pequenos mamíferos por canídeos simpátricos do sul do Brasil: sobreposição de nichos e seleção de presas. Neotropical Biology and Conservation, vol. 5, no. 1, p. 16-23. http://dx.doi.org/10.4013/nbc.2010.51.03

ACEVEDO, J. and AGUAYO, M., 2008. Leucistic South American sea Lion in Chile, with a review of anomalously color in otariids. Revista de Biología Marina y Oceanografia, vol. 23, no. 2, p. 413-417.

ACEVEDO, J., AGUAYO-LOBO, A. and TORRES, D., 2009. Albino Weddell seal at Cape Shirreff, Livingstone Island, Antarctica. Polar Biology, vol. 32, p. 1239-1243. http://dx.doi. org/10.1007/s00300-009-0680-8

BARQUEZ, RM., CARRIZO, LV., FERRO, LI., FLORES, DA., MOLLERACH, MI., SÁNCHEZ, MS. and LÓPEZ, APG., 2003. Primer caso de albinismo total para Sturnira erythromos (Tsuchudi, 1844) - (Chiroptera - Phyllostomidae). Chiroptera Neotropical, vol. 9, no. 1-2, p. 166-169.

BONNER, WN., 1968. The fur seal of South Georgia. London: British Antarctic Survey, $81 \mathrm{p}$.

BRITO, MFG. and CARAMASCHI, EP., 2005. An albino armored catfish Schizolecis guntheri (Siluriformes: Loricariidae) from an Atlantic Forest coastal basin. Neotropical Ichthyology, vol. 3, no. 1, p. 123-125.

BRUYN, PJN., PISTORIUS, PA., TOSH, CA. and BESTER, MN., 2007. Leucistic Antarctic fur Seal Arctocephalus gazella at Marion Island. Polar Biology, vol. 30, p. 1355-1358. http:// dx.doi.org/10.1007/s00300-007-0320-0

CADEMARTORI, CV. and PACHECO, SM., 1999. Registro de albinismo em Delomys dorsalis (Hensel, 1872) (Cricetidae, Sigmodontinae). Biociências, vol. 7, no. 1, p. 195-197.

CÁRDENAS, JC. and YAÑEZ, J., 1983. Variaciones extremas de color del lobo fino antártico, Arctocephalus gazella (Peters, 1875), en islas Shetland del Sur, Chile (Pinnipedia: Otariidae). Serie Científica. Instituto Antártico Chileno, vol. 30, p. 5-12.

CARRETERO, PG., JULIAN, AN., CAMPOS, SR., GUASCH, CF. and SAMPOL, LM., 2009. Síndrome de Griscelli-Prunieras: a propósito de dos casos. Anales de Pediatría, vol. 70, no. 2, p. 164-167. PMid:19217573. http://dx.doi.org/10.1016/j.anpedi.2008.10.005

EPPLEY, TM., HICKEY, JR. and NIBBELINK, NP., 2010. Observation of albinistic and leucistic Black mangabeys
(Lophocebus aterrimus) within the Lomako-Yokokala Faunal Reserve, Democratic Republic of Congo. African Primates, vol. 7, no. 1, p. 50-54.

FELDHAMER, GA., DRICKAMER, LC., VESSEY, SH., MERRITT, JF. and KRAJEWSKI, C., 2007. Mammalogy: Adaptation, Diversity, Ecology. Baltimore: The Johns Hopkins University Press. 647 pp.

FERTL, D., PUSSER, LT. and LONG, JJ., 1999. First record of an albino bottlenose dolphin (Tursiops truncatus) in the Gulf of Mexico, with a review of anomalously white cetaceans. Marine Mammal Science, vol. 15, no. 1, p. 227-234. http://dx.doi. org/10.1111/j.1748-7692.1999.tb00794.x

FERTL, D. and ROSEL, P., 2002. Albinism. In PERRIN, WF., WÜRSIG, B. and THEWISSEN, JGM. Ed. Encyclopedia of Marine Mammals. San Diego: Academic Press, vol. 2, p. 24-26.

FERTL, D., BARROS, NB., ROWLETT, RA., ESTES, S. and RICHLEN, M., 2004. An update on anomalously white cetaceans, including the first account for the pantropocal spotted dolphin (Stenella attenuata graffmani). Latin American Journal of Aquatic Mammals, vol. 3, no. 2, p. 163-166. http://dx.doi.org/10.5597/ lajam00061

FRANZ, I. and FLECK, R., 2009. Dois casos de leucismo em quero-quero Vanellus chilensis (Molina, 1782) no sul do Brasil. Biotemas, vol. 22, no. 1, p. 161-164.

FRASER, GR., SOBEY, S. and SPICER, CC., 1953. Mottled a sex-modified lethal in the house mouse. Journal of Genetics, vol. 24, p. 217-222.

GARIPIS, N. and HOFFMANN, KP., 2003. Visual defects in albino ferrets (Mustela putorius furo). Vision research, vol. 43, p. 793-800. http://dx.doi.org/10.1016/S0042-6989(03)00015-4

GEIGER, D. and PACHECO, SM., 2006. Registro de albinismo parcial em Nyctinomops laticaudatus (E. Geoffroy, 1805) (Chiroptera: Molossidae) no sul do Brasil. Chiroptera Neotropical, vol. 12 , no. 1, p. 250-254

GELLING, M., 2003. Partial albinism in the common shrew Sorex araneus. Mammal Review, vol. 33, no. 2, p. 189-190. http:// dx.doi.org/10.1046/j.1365-2907.2003.00014.x

GRANT, S., PATEL, NN., PHILP, AR., GREY, CNB., LUCAS, RD., FOSTER, RG., BOWMAKER, JK. and JEFFERY, G., 2001. Rod photopigment deficits in albino are specific to mammals and arise during retinal development. Visual neuroscience, vol. 18, p. 245-251. PMid:11417799. http://dx.doi.org/10.1017/ S095252380118209X

HAIN, JHW. and LEATHERWOOD, S., 1982. Two sighting of white pilot whales, Globicephala melaena, and summarized records of anomalously white cetaceans. Journal of Mammalogy, vol. 63, no. 2, p. 338-343. http://dx.doi.org/10.2307/1380654

HOFREITER, M. and SCHÖNEBERG, T., 2010. The genetic and evolutionary basis of colour variation in vertebrates. Cellular and Molecular Life Science, vol. 67, p. 2591-2603. PMid:20229234. http://dx.doi.org/10.1007/s00018-010-0333-7

HOFMEYR, G., BESTER, MN. and KIRKMAN, SP., 2005. Leucistic Antarctic fur seals at Bouvetøya. Polar Biology, vol. 29, p. 77-79. http://dx.doi.org/10.1007/s00300-005-0030-4

LÓPEZ, JC. and LÓPEZ, D., 1984. Sobre un caso de albinismo en el lobo marino del sur (Otaria flavescens Shaw, 1800) en Punta Norte, Península Valdés, Argentina. Actas Tercera Reunión Iberoamericana de Conservación y Zoología de Vertebrados 
(Buenos Aires, 1982). Revista del Museo Argentino de Ciencias Naturales Bernardino Rivadavia, vol. 13, no. 26, p. 255-257.

JUAREZ, KM. and MARINHO-FILHO, J., 2002. Diet, habitat use, and home range of sympatric canids in central Brazil. Journal of Mammalogy, vol. 83, no. 4, p. 925-933. http://dx.doi. org/10.1644/1545-1542(2002)083<0925:DHUAHR>2.0.CO;2

KALITA, G., 2009. Note on breeding and parental care behaviours of albino hoary-bellied squirrel Callosciurus pygerythrus (Rodentia: Sciuridae) in Sibsagar district of Assam, India. Journal of Threatened Taxa, vol. 1, no.6, p. 358-360.

MAGRINI, L. and FACURE, KG., 2008. Barn owl (Tyto alba) predation on small mammals and its role in the control of hantavirus natural reservoirs in a periurban area in southeastern Brazil. Brazilian Journal of Biology, vol. 68, no. 4, p. 733-740. PMid:19197490. http://dx.doi.org/10.1590/S1519-69842008000400007

MANCINI, PL., JIMÉNEZ, S., NEVES, T. and BUGONI, L., 2010. Records of leucism in albatrosses and petrels (Procellariiformes) in the South Atlantic Ocean. Revista Brasileira de Ornitologia, vol. 18 , no. 3 , p. $245-248$

MANGLANI, M., ADHVARYU, K. and SETH, B., 2004. Griscelli syndrome - a case report. Indian Pediatrics, vol. 41, p. 734-737. PMid:15297691.

MILLER, JD., 2005. All about albinism. Missouri Conservationist, vol. 66 , no. 6, p. 4-7.

MOREIRA, EC., SILVA, MCP. and VELOSO, JG., 1992. Albinismo em Desmodus rotundus rotundus, Chiroptera (E. Geofroy, 1810). Arquivo Brasileiro de Medicina Veterinária e Zootecnia, vol. 44, no. 6, p. $549-552$.

NASCIMENTO, LF., SPINELLI, LHP., SANTOS JUNIOR, E., QUEIROZ, REM., PANSARD, KCA., MEDEIRO, PIAP., GONDIM, MA., JESUS, AH., SILVA, FJL. and YAMAMOTO, EM., 2008. Atypical coloration in a specimen of estuarine dolphin, Sotalia guianensis, on the littoral of the state of Rio Grande do Norte, north-east Brazil. Marine Biodiversity Records, vol. 1, no. 89, p. 1-2. doi:10.1017/S1755267207008986. http://dx.doi. org/10.1017/S1755267207008986

OCHOA, J. and SANCHEZ, J., 1988. Nuevos registros de Lonchorhina fernandezi (Chiroptera: Phyllostomidae) para Venezuela, con algunas anotaciones sobre su biología. Memorias de la Sociedad de Ciencias Naturales "La Salle", vol. 48, no. 129, 133-154.

OLIVEIRA, SV., 2009a. Registro de albinismo parcial em veado catingueiro Mazama gouazoupira (G. Fischer, 1814) (Artiodactyla, Cervidae) na serra do sudeste, Rio Grande do Sul, Brasil. Biodiversidade Pampeana, vol. 7, no. 1, p. 13-15.

-, 2009b. Albinismo parcial em cutia Dasyprocta azarae Lichtenstein, 1823 (Rodentia, Dasyproctidae), no sul do Brazil. Biotemas, vol. 22, no. 4, p. 243-246.

OLIVEIRA, HFM. and AGUIAR, LMS., 2008. A new case of complete albinism in a bat from Brazil. Chiroptera Neotropical, vol. 14 , no. 2, p. 421-423.

PARSONS, GJ. and BONDERUP-NIELSEN, S., 1995. Partial albinism in an island population of Meadow Voles, Microtus pennsylvanicus, from Nova Scotia. The Canadian Field-Naturalist, vol. 109 , no. 2 , p. 263-264.

PAYNE, R., BRAZIER, O., DORSEY, EM., PERKINS, J., ROWNTREE, V. and TITUS, A., 1983. External features of the southern right whale and their use in identifying individuals.
Reports of the International Whaling Commission, Special Issue, vol. 76, p. 371-445.

PÉREZ-CARPINELL, J., CAPILLA, P., ILLUECA, C. and MORALES, J., 1992. Vision defects in albinism. Optometry and Vision Science, vol. 69, no. 8, p. 623-628. PMid:1513558. http:// dx.doi.org/10.1097/00006324-199208000-00005

PESSÔA, AL. and REIS, SF., 1995. Coat color variation in Proechimys albispinus (Geoffroy, 1838) (Rodentia, Echimyidae). Boletim do Museu Nacional, Nova Série Zoologia, vol. 361, p. 1-5.

PRESLEY, SJ., 2000. Eira barbara. Mammalian Species, vol. 636, p. 1-6. http://dx.doi.org/10.1644/15451410(2000)636<0001:EB>2.0.CO;2

RAMIREZ, NN., BOTTINELLI, OR., RUIZ, RM. and BASTOS, RS., 2010. Registro del primer caso de albinismo completo en Desmodus rotundus en Argentina. Revista Veterinaria, vol. 21, no. 1 , p. 63-65.

RAMIREZ, OE. and ARANA, M., 2005. Albinism in the andean leaf-eared mouse, Phyllotis andium (Rodentia, Cricetidae). Mastozoología Neotropical, vol. 12, no. 2, p. 269-270.

REEVES, RR., STWART, BS. and LEATHERWOOD, S., 1992. The Sierra Club Handbook of seals and sirenians. San Francisco: Sierra Club Books. 376 p.

REIS, NB., SHIBATTA, OA., PERACCHI, AL., PEDRO, WA. and LIMA, IP., 2007. Sobre os morcegos brasileiros. In REIS, NR., PERACCHI, AL., PEDRO, WA. and LIMA, IP. Morcegos do Brasil. Londrina: Universidade Estadual de Londrina. p. 17-25.

REIS, NR., PERACCHI, AL., FREGONEZI, MN. and ROSSANEIS, BK., 2010. Mamíferos do Brasil. Rio de Janeiro: Technical Books Editora. 560 p.

RODRIGUES, FHG., SILVEIRA, L., JACOMO, AT. and MONTEIRO-FILHO, ELA., 1999. Um albino parcial de veado campeiro (Ozotoceros bezoarticus, Linnaeus) no Parque Nacional das Emas, Goiás. Revista Brasileira de Zoologia, vol. 16, no. 4, p. 1229-1232. http://dx.doi.org/10.1590/S0101-81751999000400032

RONCANCIO, N. and RAMÍREZ-CHAVES, HE., 2008. Registro de leucismo em Sturnira erythromos en los Andes centrales de Colombia. Chiroptera Neotropical, vol. 14, no. 2, p. 421-423.

ROSSI, RV., BIANCONI, GV., CARMIGNOTTO, AP. and MIRANDA, CL., 2010. Ordem Didelphimorphia. In REIS, NR., PERACCHI, AL., FREGONEZI, MN. and ROSSANEIS, BK. (Ed.). Mamíferos do Brasil. Rio de Janeiro: Technical Books Editora. p. 19-74.

SABATER PI, J., 1967. An albino lowland gorilla from Rio Muni, West Africa, and notes on its adaptation to captivity. Folia primatologica, vol. 7, p. 155-160. http://dx.doi. org/10.1159/000155115

SANABRIA, EA., QUIROGA, LB. and LASPIUR, A., 2010. First Record of partial albinism and scoliosis in Odontophynus occidentalis tadpoles (Anura: Cycloramphidae). Brazilian Archieves of Biology and Technology, vol. 53, no. 3, p. 641-642. http://dx.doi.org/10.1590/S1516-89132010000300019

SÁNCHEZ-HERNÁNDEZ, C., ROMERO-ALMARAZ, ML., TABOADA-SALGADO, A., ALMAZÁN-CATALÁN, JA., SCHNELL, GD. and SÁNCHEZ-VÁZQUEZ, L., 2010. Five albino bats from Guerrero and Colima, Mexico. Chiroptera Neotropical, vol. 16, no. 16, p. 541-545. 
SAZIMA, I. and DI-BERNARDO, M., 1991. Albinismo em serpentes neotropicais. Memórias do Instituto Butantan, vol. 53, no. 2 , p. 167-173.

SAZIMA, I. and POMBAL, JP., 1986. Um albino de Rhamdella minuta, com nota sobre comportamento (Osteichthyes, Pimelodidae). Revista Brasileira de Biologia = Brazilian Journal of Biology, vol. 46, no. 2, p. 377-381.

SCHAEFF, CM., BEST, PB., ROWNTREE, VJ., PAYNE, R., JARVIS, C. and PORTWAY, VA., 1999. Dorsal skin color patterns among southern right whales (Eubalaena australis): Genetic basis and evolutionary significance. The American Genetic Association, vol. 90, p. 464-471.

SILVA, FA., ASSIS, CL. and QUINTELA, FM., 2010. Albinism in a Liophis miliaris (Linnaeus, 1758) (Serpentes: Dipsadidae) from Minas Gerais State, southern Brazil. Herpetology Notes, vol. 3, p. 171-172.

SODRE, MM., UIEDA, W. and BALDIM, M., 2004. First record of albinism in the bat Eumops glaucinus (Molossidae) from southeastern Brazil. Chiroptera Neotropical, vol. 10, no. 1-2, p. 200-201.

SOUSA, KS. and BAGER, A., 2008. Feeding habits of Geoffroy's cat (Leopardus geoffroyi) in southern Brazil. Mammalian Biology, vol. 73, p. 303-308. http://dx.doi.org/10.1016/j.mambio.2007.04.001

SUMMERS, CG., 2009. Albinism: classification, clinical characteristics, and recent findings. Optometry and Vision Science, vol. 86, no. 6, p. 659-662. PMid:19390472. http://dx.doi. org/10.1097/OPX.0b013e3181a5254c

TIETZ, W., 1963. A syndrome of deaf mutism associated with albinism showing dominant autosomal inheritance. American Jurnal of Human Genetics, vol. 15, p. 259-264. PMid:13985019 PMCid:1932384.

TORTATO, FR. and ALTHOFF, SL., 2007. Variações na coloração de iraras (Eira barbara Linnaeus, 1758 - Carnivora, Mustelidae) da Reserva Biológica Estadual do Sassafrás, Santa Catarina, sul do Brasil. Biota Neotropica, vol. 7, no. 3, p. 365-367. http:// dx.doi.org/10.1590/S1676-06032007000300038
UDVARDY, MDF. 1975. A classification of the biogeographical provinces of the world. IUCN Occasional Paper, no. 18

UIEDA, W., 2000. A review of complete albinism in bats with five new cases from Brazil. Acta Chiropterologica, vol. 2, no. 1, p. $97-105$.

-, 2001. Behaviour of an albino vampire bat, Desmodus rotundus (E. Geoffroy) (Chiroptera, Phyllostomidae), in captivity. Revista Brasileira de Zoologia, vol. 18, no. 2, p. 641-644. http://dx.doi. org/10.1590/S0101-81752001000200031

VACCARO, O. and CANEVARI, M., 2007. Guía de Mamíferos del Sur de América del Sur. Buenos Aires: Literature of Latin América. $413 \mathrm{p}$

VEIGA, LA., 1994. Um caso de albinismo em Tayassu tajacu Linnaeus (Artiodactyla, Tayassuidae) na Serra do Mar, São José dos Pinhais, Paraná. Revista Brasileira de Zoologia, vol. 11, no. 2, p. 341-343. http://dx.doi.org/10.1590/S0101-81751994000200019

VEIGA, LA. and OLIVEIRA, AT., 1995a. Um caso de albinismo completo em morcego Molossus molossus, Pallas (Chiroptera, Molossidae) em Santa Vitória do Palmar, RS., Brasil. Arquivos de Biologia e Tecnologia, vol. 38, no. 3, p. 879-881.

-, 1995b. Um caso de albinismo em tacha (Cauna torquata, Oken) (Aves, Anseriformes) ocorrido na Estação Ecológica do Taim, Rio Grande do Sul, Brasil. Revista Brasileira de Zoologia, vol. 12, no. 3, p. 563-566. http://dx.doi.org/10.1590/S0101-81751995000300011

XAVIER, GAA., OLIVEIRA, MAB., QUIRINO, AA., MOTA, RA., 2010. Albinismo total em preguiças-de-garganta-marrom Bradypus variegatus (Schinz, 1825) no Estado de Pernambuco, Brasil. Edentata, vol. 11, no. 1, p. 1-3

WALTER, HE., 1914. Genetics: An Introduction of Study of Heredity. New York: Mac-Millan. 272 p.

WILSON, DE. and REEDER, DAM., 2005. Mammals Species of the World: A Taxonomic and Geographic Reference. Baltimore: The Johns Hopkins University Press. 2142 p.

ZIPKOWSKI, L., KRAKOWSKI, A., ADAM, A., COTEFF, H. and SADE, J., 1962. Partial albinism and dead-mutism due to a recessive sex-linked gene. Archives of Dermatology, vol. 86, p. 530-539. http://dx.doi.org/10.1001/archderm.1962.01590100144027 